March 1959

The Journal of

\title{
Laryngology and Otology
}

\author{
EDITED BY \\ WALTER HOWARTH
}

ASSISTANT EDITOR

G. H. BATEMAN

\section{Contents}

THE Modern Treatment OF Deafness in Historical Perspective.

Modern Views on Vestibular Physiology.

IDIOPATHIC RECURRENT LARYNGEAL NERVE PARALYSIS

Occupational Deafness Among Hearing Am TECHNICIANS .

Hamanglomas OF THE NOSE

IMPAIRMENT AND RECOVERX OF TASTE FOLLOWING IRRADIATION OF THE OROPHARYNX . .

CLINICAL ReCORDS-

A Case of Hand-Schüller-Christian Disease WITH EAR INVOLVEMENT, WTTH FOLLOW-UP AFTER 9 YEARS

The Assoctation of LARYNGeal Stridor WITH MENINGO-MYELOCELE

A Branchiogenic Cyst of the NASOPHARYNX Symmetrical AuRAL COMPLiCATIONS OF A HEAD INJURY

RELIEE OF DEAFNESS, FOLLOWING REPLACEMENT of aN INcus Dislocated 16 Years PreVIOUSLY

General Notres

T. G. WIIsonv Gösta DoHLMan R. G. WIILIAMS

R. E. Jowetr and J. S. M. DAVEY

D. A. OSBORN

H. KaLMUS and DEAN FARNSWORTH

A. D. WIILSON and W. S. SOMMERFELD

M. E. N. SмrxH

C. Petrer Mitls

P. COLE and

R. H. D. Sxkes

JAMES FREEMAN ${ }^{-}$

London

Headley Brothers Ltd 109 Kingsway $\mathrm{WC}_{2}$ 



\section{The Journal of Laryngology and Otology}

\section{CONTENTS}

PAGE

The Modern Treatment of Deafness in Historical Perspective,

T. G. Wilson (Dublin) . . . . . . . $\quad$. 149

Modern Views on Vestibular Physiology. Gösta Dohlman

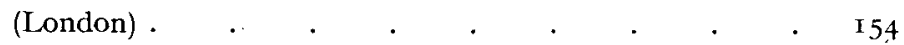

Idiopathic Recurrent Laryngeal Nerve Paralysis. R. G. Williams (London) . . . . . . I6I

Occupational Deafness Among Hearing Aid Technicians. R. E. Jowett and J. S. M. Davey (Sunderland) . 167

Hemangiomas of the Nose. D. A. Osborn (London) . . 174

IMPairment and Recovery of Taste following IrRadiation of The OropharynX. H. Kalmus and Dean Farnsworth (London) .

Clinical Records-

A Case of Hand-Schüller-Christian Disease with Ear Involvement, with Follow-up after 9 Years. A. D. Wilson (Nazareth) and W. S. Sommerfeld (Affulah)

The Association of Laryngeal Stridor with Meningo-Myelocele. M. E. N. Smith (Swansea)

A Branchiogenic Cyst of the Nasopharynx. C. Peter Mills (London) .

Symmetrical Aural Complications of a Head Injury. P. Cole and R. H. D. Sykes (Brandon, Manitoba)

Relief of Deafness, following Replacement of an Incus Dislocated I6 Years Previously. James Freeman (Bristol) .

For Advertisement space in this Journal apply to: HEADLEY BROTHERS Ltd, 109 Kingsway London WC 2 


\title{
The Journal of Laryngology and Otology
}

(Founded in 1887 by Morell Mackenzie and Norris Wolfenden)

\author{
EDITED BY \\ WALTER HOWARTH
}

ASSISTANT EDITOR

G. H. BATEMAN

I. Original Articles are accepted on the condition that they have not been published elsewhere.

2. Manuscripts should be typewritten, on one side only of the paper, and well spaced. Captions to illustrations should be typed on a separate sheet and sent at the same time as original photographs, etc.

The Harvard system of recording references should be used, e.g. Green, C., and Brown, D. (195I) J. Laryng., 65, 33. Abbreviations of Journals should follow the style recommended in World Medical Periodicals, published by World Health Organization 1952.

It is most important that authors should verify personally the accuracy of every reference before submitting a paper for publication.

3. Galley proofs and engraver's proofs of illustrations are sent to the author. Corrections, which should be kept to a minimum, must be clearly marked, and no extra matter added. Proofs should be returned within s days.

4. Illustration blocks are provided free up to the limit of fio per article; beyond this authors are expected to pay half the cost. Coloured illustrations will be charged in full to authors.

Blocks will normally be held by the Printers for three years after which they will be destroyed. Any author who has borne a part of the cost of his blocks is entitled to have these returned to him, but a request for this must be sent within three years of the appearance of the article, to Headley Brothers LTD., IOg Kingsway London, WC2.

5. Orders for reprints should be sent when returning galley proofs, and for this purpose special forms are supplied.

6. Authors of original communications on Oto-Laryngology in other journals are invited to send a copy, or two reprints, to the Journal of Laryngology. If they are willing, at the same time, to submit their own abstract (in English, French, Italian, or German) it will be welcomed.

7. Editorial communications may be addressed to ThE EDrTor, Journal of Laryngolugy, c/o HeAdrey BROTHers LTD., IO9 Kingsway, London, WC2.

8. The annual subscription is four guineas sterling (U.S.A. \$13) post free, and is payable in advance.

9. Single copies will be on sale at ros. od. each; copies of parts up to Vol. LXIII may be purchased at $4 \mathrm{~s}$. each.

10. All subscriptions, advertising and business communications should be sent to the publishers, Headley Brothers Lrd., Iog Kingsway London, WC2.

Orders for this Journal may be sent through local bookseller, or to Stechert-HafNer, INC., 31-33 East Ioth Street, New York, or direct to the publishers, Headley Brothers Ltd., iog Kingsway London, WC2, England. 


\section{When a}

\section{hearing}

aid is

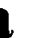

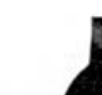

advised ...

- you may confidently

recommend your patients to S. C. INGHAM

$\star \quad$ They can try the different makes of hearing aids

$\star$ They get impartial advice on all makes of hearing aids

$\star$ Their personal needs are given individual and continued attention

$\star A$ full report on each fitting recommended is sent to the patient's ear specialist

$\star$ They can compare at one consultation the different makes one with another

\section{S. C. INGRAM Independent Hearing Aid Consultant}

On the approved List of the National Institute for the Deaf

2 SHEPHERD STREET, SHEPHERD MARKET, LONDON, W.I

Hyde Park 9042

Please mention The Journal of Laryngology and Otology when replying to advertisements 


\section{Now in wide use... Biomydrin the complete nasal spray}

MUCOLYTIC

DECONGESTANT

ANTIBACTERIAL

\author{
ANTI-ALLERGIC
}

\begin{abstract}
Biomydrin's unique penetrating agent, thonzonium bromide, ensures that the medication reaches affected sites. It also liquefies and loosens thick clinging mucus.
\end{abstract}

Biomydrin contains a safe vasoconstrictor, phenylephrine, which improves ventilation and facilitates adequate discharge. It is non-toxic with minimal rebound effects, and remains effective even after prolonged use. It does not give rise to central stimulation.

Biomydrin employs two antibiotics: neomycin and gramicidin. This combination provides broad bactericidal action against the gram-positive and gramnegative pathogens generally met with in infectious rhinitis and sinusitis.

Biomydrin incorporates the safe, effective anti-allergic substance thonzylamine hydrochloride, to control the allergic reactions which are often an important element in rhinitis.

PACKAGING: Pocket-size plastic atomizer bottle containing $\frac{1}{2}$ fluid ounce.

PRESCRIPTION: Blomydrin 1 original pack.

Formula: Neomycin Sulphate $0.1^{\prime \prime}$ ', Gramicidin $0.005 '$ ', Thonzylamine Hydrochloride $1.0^{\prime}$ ', Phenylephrine Hydrochloride $0.25^{\circ}$, Thonzoniwn Bromide $0.05 \mathrm{~N}_{\mathrm{o}}$, Preserved with Thiomersal $0.002 \mathrm{\%}_{\mathrm{o}}$

Full literature is available on request to:

WILLAM R. WARNER \& CO. LTD. EASTLEIGH, HAMPSHIRE 


\section{In schools for the DEAF- multitone Telesonic INDUCTION LOOP SYSTEM brings new advantages}

1 Can be installed in adjoining classrooms without risk of 'spill over'.

2 Combines good hearing with complete freedom of movement. Unaffected by distance between pupil and teacher.

3 Clear speech at high amplification.

4 Any number of pupils may use the same installation.

5 The child can use the instrument as a normal hearing aid outside school.

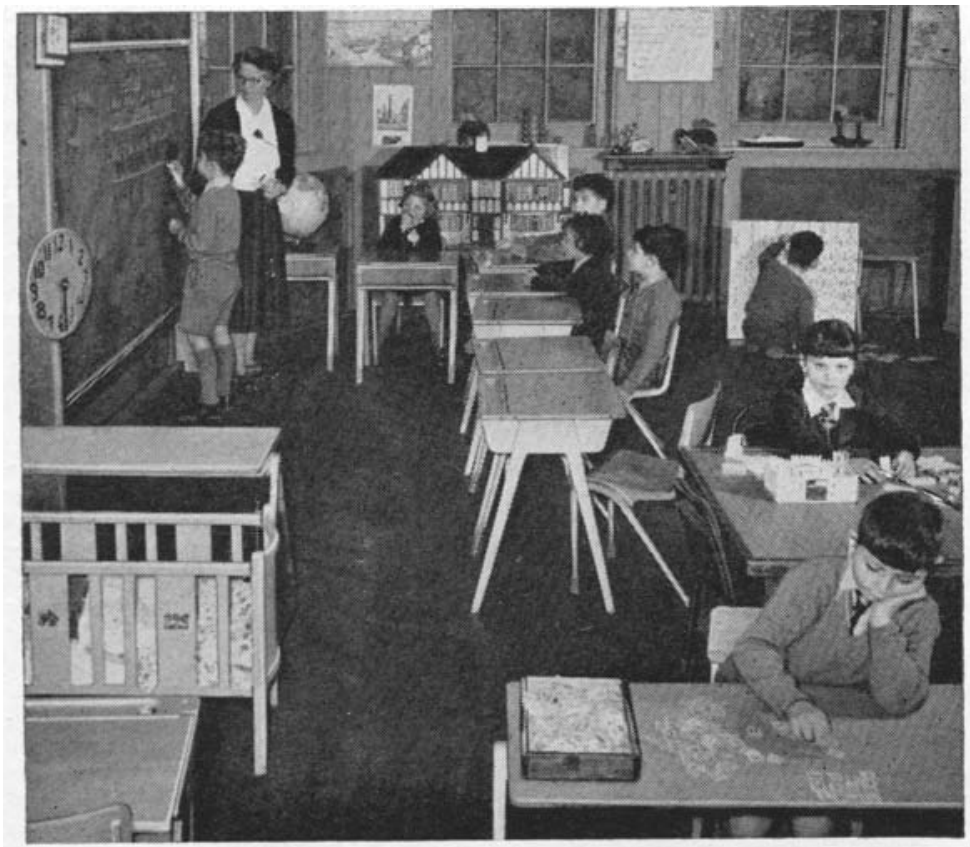

The Kindergarten Class at the London Residential School for Jewish Deaf Children where all classrooms have been installed with the Multitone Telesonic Induction Loop System

Write for further details to:

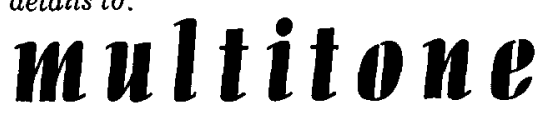

ELECTRIC COMPANY LTD., 12.20 UNDERWOOD STREET, LONDON, N.I.

CRC $M 23$

Please mention The Journal of Laryngology and Otology when replying to advertisements 


\section{THE}

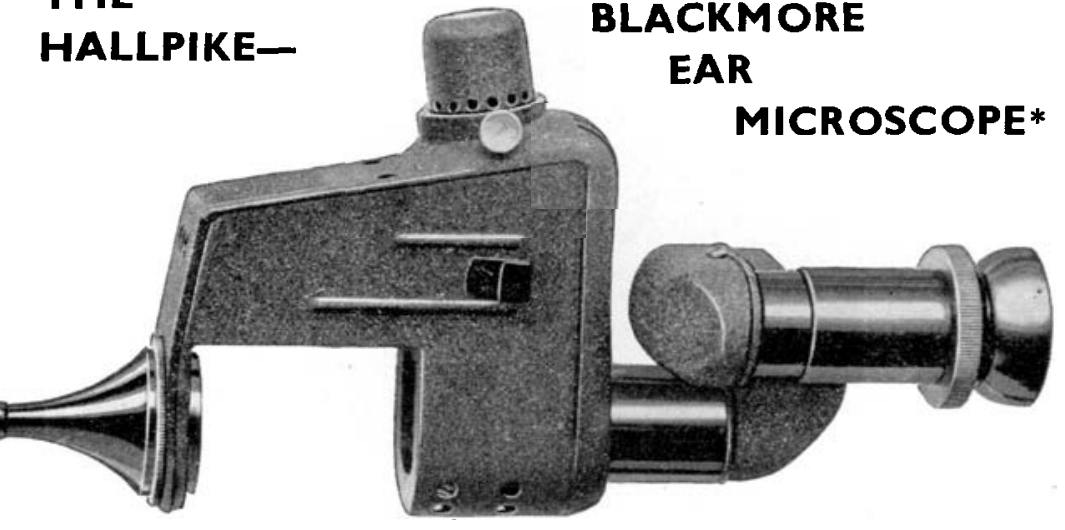

\section{DIAGNOSIS}

U S E S

The excellent optical performance of the Hallpike Ear Microscope gives the user greatly increased confidence in the diagnosis of abnormal conditions; and many disorders may be recognized at an earlier stage than has hitherto been possible with "headlamp and speculum" techniques. Thus slight pulsation of swellings and vascular tumours - of high diagnostic significance and almost impossible to detect by conventional methods-can readily be detected under this microscope.

Use of the Siegle attachment permits observation of small bubbles present in fluid collections within the tympanum; it is also invaluable for demonstrating minute perforations. Where defects of the tympanic membrane are present, the middle-ear cavity can be scrutinized minutely; the detailed structure of the stapes, stapedius tendon, round window and Eustachian orifice-not normally visible by ordinary methods of examination-are seen with quite remarkable clarity when the Ear Microscope is used.

\section{TREATMENT}

Manipulative procedures may be undertaken with greater confidence and precision if the Ear Microscope and its special instruments are used.

The curettes enable adherent wax and debris to be removed with the greatest precision from the walls of the deep meatus or from the tympanic membrane itself. Cholesteatomatous masses or neoplasms may be examined critically and biopsy specimens obtained by means of the curettes. These may also be used as delicate probes for palpation of the incus and head of the stapes in certain cases of otosclerosis with retraction and atrophy of the tympanic membrane; in this way unmistakable evidence may be obtained of bony fixation of the footplate. Or again, it is sometimes possible to identify by palpation defects of the bony tympanic ring or meatal wall which may underlie granulations.

Myringotomy or removal of foreign bodies can be undertaken with surprisingly high precision because the optics of the Ear Microscope and the specially angled myringotome blade eliminate all shadows so that the surgeon can see clearly where and what he is cutting. The outfit is invaluable also for postoperative examinations and treatment of mastoid cavities. Granulations can be cauterized and exposed areas of dura mater carefully palpated.

$$
\text { *J. Laryng. (1953) 67, } 108 .
$$




\title{
An outstanding accomplishment
}

\author{
in hearing aid design
}
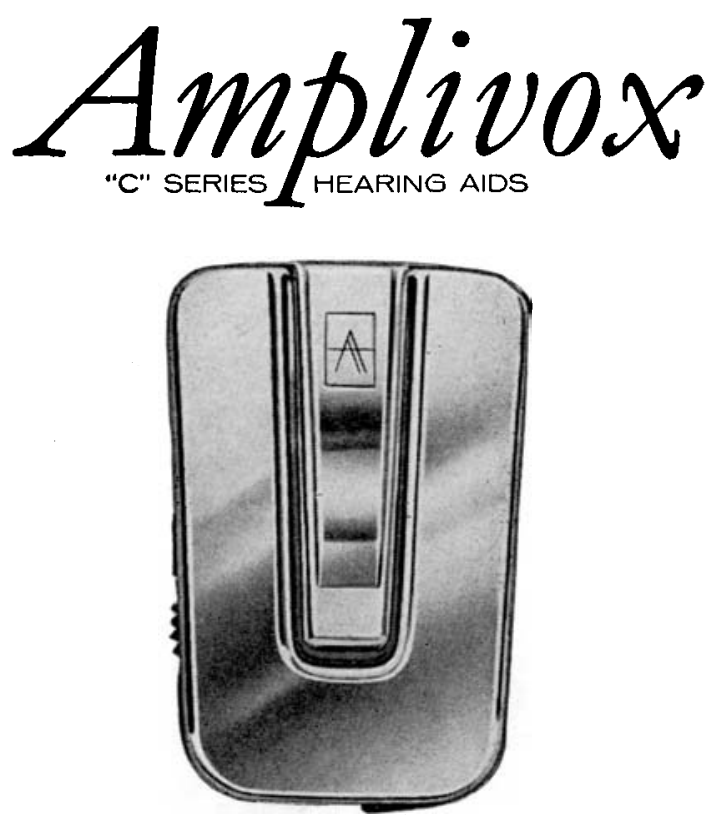

\section{FACILITIES}

Individual fitting related to the Audiogram by means of selective compensation. Tone control giving low frequency attenuation combined with an overall response extending to $4000 \mathrm{c} / \mathrm{s}$ provides excellent speech discrimination in cases of perceptive deafness.

\section{S P E C I F I CATION}

4 stage transistor circuit. Stable operation from $0^{\circ}$ to $40^{\circ} \mathrm{C}$.

Miniature earphone with extended response. Magnetic microphone. Telephone inductor. Mercury cell battery -life Ioo hours. Size $2 \frac{1}{8} " x \mathrm{I}_{16}^{1} " x \frac{15}{32} "$ Weight I oz.

Mirror gold finish.

Two-stage adjustable automatic volume compression.

\begin{abstract}
A MPLIVOX LTD. LONDON. ENGLAND $47 / 48$ New Bond Street, London, W.1. Hyde Park 9888 WORLD-WIDE DISTRIBUTION AND SERVICE
\end{abstract}




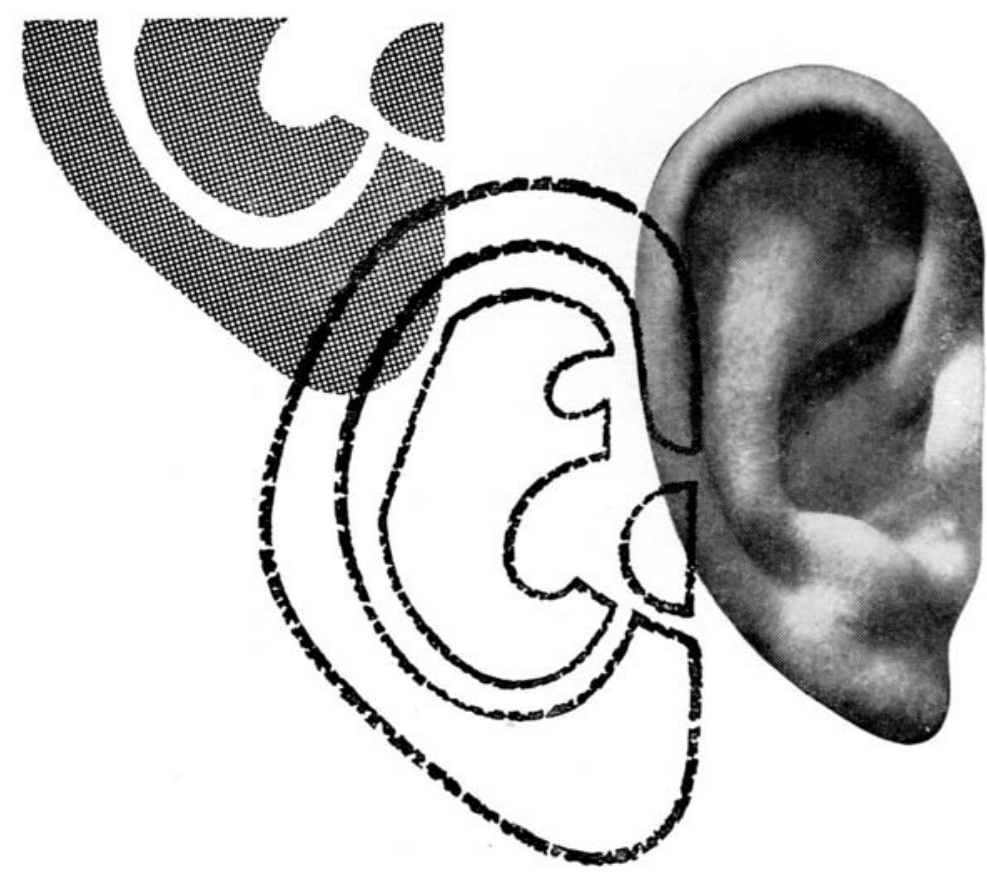

\section{'OTOSPORIN'}

\section{clears infected ears}

The modern method of treatment in otitis externa, chronic suppurative otitis media, and infected mastoid cavities, is 'Otosporin' brand Drops.

'Otosporin' is an aqueous suspension containing both neomycin ( 5 mgm. per c.c.) and polymyxin $B$ sulphate $(10,000$ units per c.c.) which are together effective against practically all the bacteria found in ear infections. They are unlikely to induce bacterial resistance or skin sensitisation, and neither of them gives rise to cross-resistance or cross-sensitisation to penicillin and other antibiotics. Their effectiveness is visibly enhanced by the hydrocortisone $(5 \mathrm{mgm}$. per c.c.) in 'Otosporin'; this, by reducing inflammation, not only relieves pain, but provides greater access for the antibiotics.

\section{‘OTOSPORIN”drops} issued in bottles of 5 c.c.

BURROUGHS WELLCOME \& CO. (The Wellcome Foundotion Ltd.) LONDON

Please mention The Journal of Laryngology and Otology when replying to advertisements 